\title{
Soil Restoration through the Application of Organic Mulch Following Skidding Operations Causing Vehicle Induced Compaction in the Hyrcanian Forests, Northern Iran
}

\author{
Azadeh Khoramizadeh ${ }^{1}$, Meghdad Jourgholami ${ }^{1}$,, Mohammad Jafari ${ }^{2}$, Rachele Venanzi ${ }^{3}$, Farzam Tavankar ${ }^{4}(\mathbb{D}$ \\ and Rodolfo Picchio ${ }^{3, *}$ (1) \\ 1 Department of Forestry and Forest Economics, Faculty of Natural Resources, Alborz Campus, University of \\ Tehran, Karaj 14176-43184 , Iran; a.khorami_69@ut.ac.ir (A.K.); mjgholami@ut.ac.ir (M.J.) \\ 2 Department of Reclamation of Arid \& Mountainous Regions, Faculty of Natural Resources, Alborz Campus, \\ University of Tehran, Karaj 14176-43184 , Iran; jafary@ut.ac.ir \\ 3 Department of Agriculture and Forest Sciences (DAFNE), University of Tuscia, 01100 Viterbo, Italy; \\ venanzi@unitus.it \\ 4 Department of Forestry, Khalkhal Branch, Islamic Azad University, Khalkhal 56817-31367, Iran; \\ tavankar@aukh.ac.ir \\ * Correspondence: r.picchio@unitus.it; Tel.: +39-0761357400
}

check for

updates

Citation: Khoramizadeh, A.; Jourgholami, M.; Jafari, M.; Venanzi, R.; Tavankar, F.; Picchio, R. Soil Restoration through the Application of Organic Mulch Following Skidding Operations Causing Vehicle Induced Compaction in the Hyrcanian Forests, Northern Iran. Land 2021, 10, 1060. https://doi.org/10.3390/land10101060

Academic Editor: Cezary Kabala

Received: 21 September 2021

Accepted: 5 October 2021

Published: 9 October 2021

Publisher's Note: MDPI stays neutral with regard to jurisdictional claims in published maps and institutional affiliations.

Copyright: (c) 2021 by the authors. Licensee MDPI, Basel, Switzerland. This article is an open access article distributed under the terms and conditions of the Creative Commons Attribution (CC BY) license (https:/ / creativecommons.org/licenses/by/ $4.0 /)$.

\begin{abstract}
In this study an attempt was made to assess how different mulches affect the soil environment. In particular, different organic mulches such as leaf litter, straw and sawdust were tested in order to assess their capacities to amend the soil conditions. These analyses were carried out in the Hyrcanian mixed broadleaved forest. Organic mulches can compensate the litter layer loss on compaction-induced soil and accelerate the restoration process of soil properties, which takes from a few years to several decades without mulching. However, comprehensive knowledge on the effects of organic mulch on soil quality in terms of compaction-induced soil in the scientific literature is still scarce and inadequate. The main aim of the study was to examine the effects of three organic mulches (leaf litter, straw and sawdust) on the restoration of forestry vehicle-induced soil properties in the skid trail over a 2-year period. The results showed as the values of soil physical and chemical properties in litter, straw and sawdust treatments were significantly restored as compared with the values in the untreated soil. In general, leaf litter supplies nutrients at higher rates than the straw and sawdust mulches. However, according to the current results, a 2-year period is not enough to return the soil physical and chemical properties to pre-traffic levels. Furthermore, the present study shows that organic mulch spread on the surface of mineral soil in the skid trails after machine traffic acts as a fertilizer to accelerate the decomposition of organic matter.
\end{abstract}

Keywords: forest harvesting; skid trail; soil compaction; leaf litter; sawdust; straw; soil recovery

\section{Introduction}

The increase in demand of wood products brought about more use of heavy machinery in logging operations. As a result, the adverse impacts on forest soil have become more extensive and severe [1]. Forest harvesting operations along with the movement of heavy machinery on the surface of skidding trails not only removes the canopy cover but also causes soil disturbances and removal of the litter layer from the forest floor [2,3]. Forestry vehicle traffic on the forest soil surface exerts considerable stress onto the soil layer, which increases soil strength and soil bulk density, reduces total porosity and gas exchange, decreases pore connectivity and reduces soil aeration, thus leading to an increase in soil penetration resistance $[4,5]$. This also causes the subsequent inhibition of root elongation and propagation into soil, and so reducing tree and seedling growth [6-8]. The reduced level of evapotranspiration caused by the removal of canopy cover also reduces rainfall interception. The result is that raindrops directly hit the surface of the mineral soil, which 
causes the detachment of soil particles, reduces water permeability and enhances volumetric soil water content. The increase in surface runoff caused by the increased kinetic energy of water and suspended solids leads to an increase in soil erosion and nutrient loss [9-12].

Mulch is defined as any organic or inorganic material that spreads on soil surface increasing coverage and providing protection [13-15]. Mulch not only protects the surface of the soil and plays a crucial role in soil and water conservation but also amends soil quality and introduces a favorable environment by the decomposition process of mulch substrates [16,17]. Most of the studies related to mulch have been carried out in agricultural areas both on its effect in reducing runoff and sediment and in improving soil quality [14-16]. Concerns about the application of mulch in forest management have focused mainly on its use after wildfires for mitigating surface runoff and sediment [18-24]. Few studies have been conducted on other types of applications of mulch to prevent runoff and soil erosion in compacted soils of skid trails and the effects on soil quality and amendment [2,12,25-29].

Organic mulches help to enhance the soil nutrient pool by increasing the organic matter content which enhances soil physical and chemical quality [17]. The decomposition time of mulch has a wide range that depends on the type of mulch $[14,30]$. During the decomposition of mulch, the amount of nutrients released within the pool and the organic matter content highly depends on the mulch type and application rate [31]. Soil structure and aggregate stability both play an important role in maintaining soil quality and the nutrient pool, which are determined by organic mulches [13,16]. Aggregation is improved by the increased content of soil organic matter which is a product of the process of decomposition of the mulch applied onto the surface [25,32]. There is also an increase in the activity of micro-organisms, root elongation and organic substances after mulching. Moreover, mulching contributes to the formation of aggregates and enhances aggregate stability. Studies have concluded that the higher the rate of mulch application the higher the increase in aggregate stability $[14,17,31]$.

The application of organic mulch absorbs raindrop impact, improves surface roughness and increases water infiltration into the soil layer, which reduces runoff and soil erosion $[13,14,16,30]$. Previous studies have reported that surface applied mulches significantly improved the concentration of soil organic matter content $[9,20,30]$. By applying the wheat straw mulch at $0,2,4,8$ and $16 \mathrm{Mg} \mathrm{ha}^{-1}$ year $^{-1}$, Mulumba and Lal [20] reported that soil bulk density increased as mulch rate increased from 0 to $5 \mathrm{Mg} \mathrm{ha}^{-1}$, but further increase in mulch rate led to a decrease in soil bulk density. Soil biotic and abiotic factors were also affected by mulch, which determined pore space and continuities [12]. Previous studies have reported a positive linear relationship between mulch application rate and soil penetration resistance [2,8,12]. Mulumba and Lal [20] indicated that total porosity increased by $35-46 \%$ after mulch application. The improvement of soil porosity following mulch application has shown to be crucial in increasing stand productivity. This is due to its effects on soil aeration, which enhances root growth thus leading to the absorption of adequate nutrients [2,12]. Mulch application intercepts solar radiation, reduces temperature fluctuations, regulates soil temperature and energy entering into the soil layer depending on its potential to reflect and transmit solar energy, which strongly affects the rate of soil biological and chemical processes [14]. The effectiveness of mulch for reducing runoff and soil erosion depends on the application rate of mulch. It has been observed that even low mulch rates have a significant effect on soil and water conservation [15,31]. By applying wheat straw residues at $0,1,5,10$ and $15 \mathrm{Mg} \mathrm{ha}^{-1}$ year $^{-1}$ in the Mediterranean area, Jordán et al. [31] recommended that wheat straw mulching rates of $5 \mathrm{Mg} \mathrm{ha}^{-1}$ year $^{-1}$ can be effective to reduce runoff and soil erosion over a 3-year period. In addition, Li et al. [15] concluded that $6-8 \mathrm{Mg} \mathrm{ha}^{-1}$ mulching rates can be effective for decreasing runoff and soil loss. Some mulch with recalcitrant $C$ has a different effect on the soil organic carbon pool as compared to the mulch with labile fraction $[14,16]$. Surface applied mulch can modify the soil nutrient pool depending on the mulch type and its labile component [14]. During the decomposition process of organic mulch, the nutrients are released and become available 
for plant root uptake [16]. Ugawa et al. [11] found that slash scattering on the compacted soil augmented soil $\mathrm{N}$ mineralization and nitrification rates.

Leaf litter has some influence on the physical and chemical properties of soil, which modify the soil nutrient pool during the decomposition processes [33-36]. Generally, the litter quality is the main driver that regulates litter decomposition and supplies nutrients for plant uptake [35,37-39]. In forest stands, leaf litter protects the mineral soil from droplet impacts and regulates the nutrients cycling [22,40]. Tree species with leaves and root-soil interactions also have an influence on the forest litter layer and soil properties [34,40,41]. Litter $\mathrm{C}$ and $\mathrm{N}$, soil $\mathrm{C}$ and lignin are the main drivers for the $\mathrm{C} / \mathrm{N}$ ratio, which influences the litter quality, decomposition and microbial and biological activity of soil [33,40,42]. The application of high-quality litters (e.g., hornbeam and maple) could be more effective than low quality litter such as beech litter for restoring soil organic carbon and supplying nutrients [26]. However, Jourgholami et al. [2] concluded that the restoration of soil properties in the litter incorporation was higher than litter mulching in the skid trails. Diao et al. [36] found that some native tree species have significant effects on soil properties. Some litter of tree species with recalcitrant compounds (e.g., lignin, tannins and polyphenols) decomposed faster than the others leading to a higher diversity in microbial populations and releasing more nutrient content $[43,44]$. Accordingly, Jourgholami et al. [8] indicated that the recovery level was higher in litter mulch than the straw mulch within 3 years after applying mulch on the compacted soil due to higher organic $\mathrm{C}$ and total $\mathrm{N}$ in the mixed litters of hornbeam, Caucasian alder and velvet maple, which led to a faster decomposition rate of litter mulch than straw mulch. Sawdust mulch as lignified material with a high $\mathrm{C} / \mathrm{N}$ ratio can alter soil condition acting as an acidifier [16].

Organic mulches can compensate the litter layer loss on compaction-induced soil and accelerate the restoration process of soil properties, which takes from a few years to several decades without mulching [1,5,45]. However, comprehensive knowledge on the effects of organic mulch on soil quality in terms of compaction-induced soil in the skid trails in the scientific literature is still scarce and inadequate. It is imperative to evaluate how different mulches affect the soil environment and to know the effect of different organic mulches such as leaf litter, straw and sawdust on the amendment of soil conditions. The objectives of the study were to (1) examine the effects of three organic mulches (leaf litter, straw and sawdust) on the restoration of forestry vehicle-induced soil properties in the skid trail over a 2-year period, and (2) determine the optimal application rate of the three mulches on the recovery level of soil physico-chemical properties.

\section{Materials and Methods}

\subsection{Site Description}

This study was conducted in the compartments of 207 and 212 in the Kheyrud Forest Research Station of The University of Tehran, in the the Hyrcanian forests of northern Iran $\left(51^{\circ} 37^{\prime} 01^{\prime \prime}-51^{\circ} 37^{\prime} 17^{\prime \prime} \mathrm{E}, 36^{\circ} 33^{\prime} 34^{\prime \prime}-36^{\circ} 33^{\prime} 15^{\prime \prime} \mathrm{N}\right.$ ) (Figure 1a), which is located in a temperate zone. The study area is predominantly south-facing with an elevation ranging from 820 to $970 \mathrm{~m}$. The average of study area slope is $\sim 25 \%$. Forest vegetation in the study area is dominated by stands of beech (Fagus orientalis Lipsky), hornbeam (Carpinus betulus L.) and velvet maple (Acer velutinum Boiss.). Soils are well drained and deep brown (Alfisols [U.S. Soil Taxonomy]). Geology is primarily limestone and dolomite limestone, belonging to the upper Jurassic and lower Cretaceous periods. The mean annual precipitation ranges between 1081 and $1172 \mathrm{~mm}_{\text {year }}{ }^{-1}$. The annual mean air temperature is $\sim 8.6^{\circ} \mathrm{C}$. July is the hottest month with monthly mean temperature of $18.1^{\circ} \mathrm{C}$ and January is the coldest month with monthly mean temperature of $-4{ }^{\circ} \mathrm{C}$. In two compartments, 75 ha of the Namkhaneh district was harvested as a single and group selection method in March 2017. Forest harvesting operations consisted of tree felling by chainsaw and extracted 54 trees in an area of $319 \mathrm{~m}^{3}$ in compartment no. 207 and 32 trees in an area of $270 \mathrm{~m}^{3}$ in compartment no. 212 using a wheeled skidder TAF E655 from stump to landings in September 2017. The main characteristics of the TAF E655 skidder are as follows: articulated, four-wheel-drive 


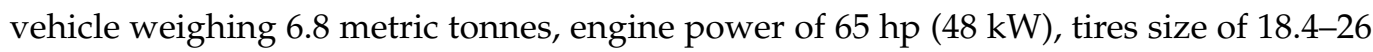
inflated to $659 \mathrm{kPa}$ on both front and rear axles, overall width of $2.85 \mathrm{~m}$. The average volume per turn was $2.16 \mathrm{~m}^{3}$. The slope gradient of skid trails ranged $5-11 \%$. The skid trail was $780 \mathrm{~m}$ in length and $3.5 \mathrm{~m}$ in width.
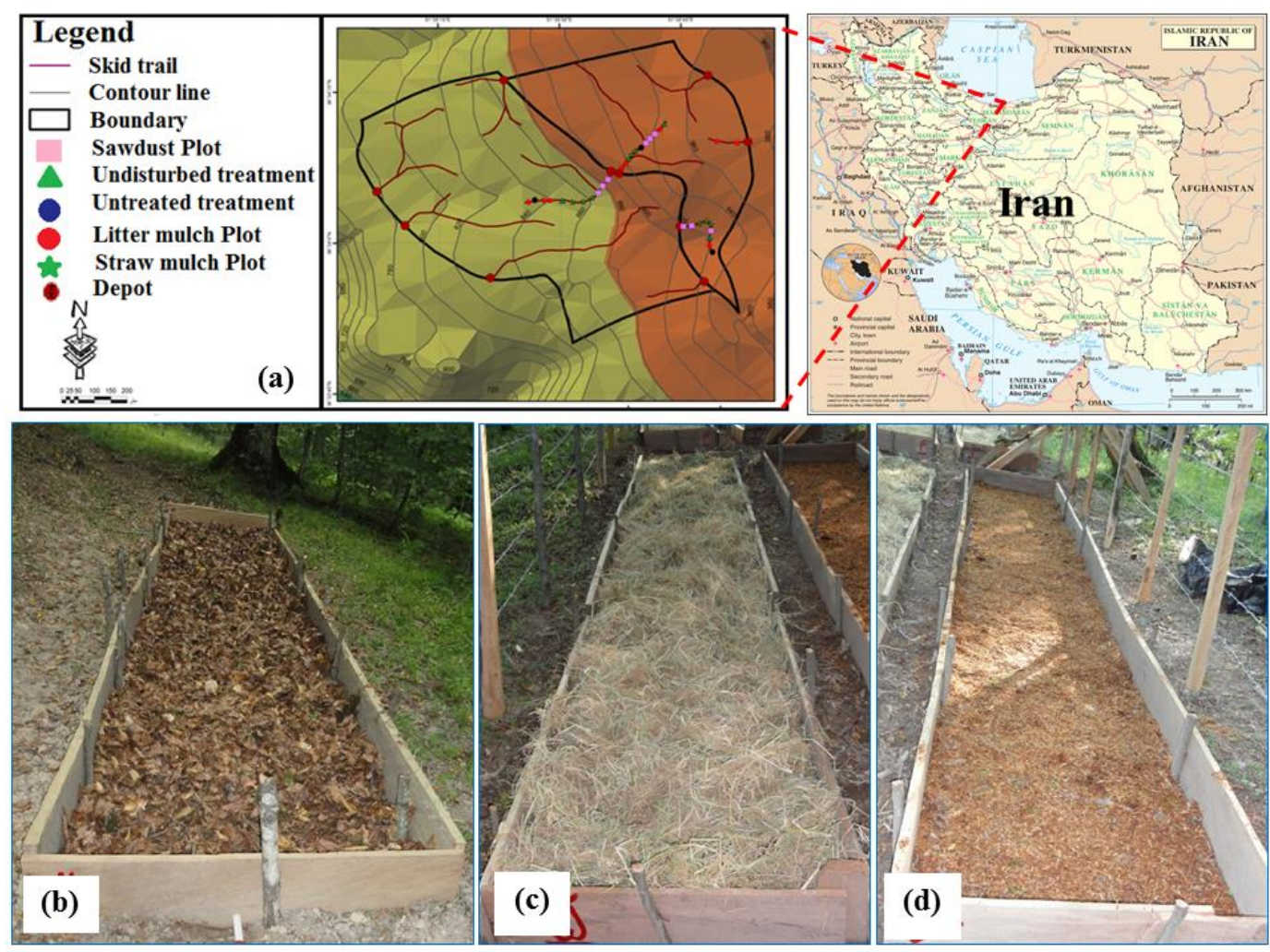

Figure 1. The study area in Namkhaneh District in the Hyrcanian forests (a), skid trail with litter mulch level of $12.2 \mathrm{Mg}^{-1}$ (LM12.2, b), skid trail with straw mulch level of $11.4 \mathrm{Mg} \mathrm{ha}^{-1}(\mathrm{SM} 11.4, \mathrm{c})$; skid trail with sawdust mulch level of $22.2 \mathrm{Mg}^{-1}$ (SDM22.2, d).

\subsection{Experimental Design}

Sampling sites including four skidding paths were selected according to the similarity in terms of vegetation, topography, soil characteristics in the two adjacent compartments, according to the predominant slope of skidding paths (10-15\%). The location of sample plots was randomly selected. Immediately after the skidding operations in September 2017, the mulch applications were spread onto the sample plots. Considering three types (i.e., litter, straw and sawdust) of mulch and three replicates, as well as the undisturbed area (UND) and untreated skid trail (UNT), a total of 33 plots with dimensions of $1 \times 6 \mathrm{~m}$ were installed on wheel ruts in the study area for mulch application. The undisturbed plots (UND) were positioned within $20 \mathrm{~m}$ far from the skid trails. For litter mulch treatments on the soil surface, a mixed litter of beech and hornbeam was manually distributed on the surface soil at the plot with three applying levels of 6.2 (LM6.2), 12.2 (LM12.2) and 18.6 (LM18.6) $\mathrm{Mg} \mathrm{ha}^{-1}$ after machine passes and plot establishment. The undecomposed mixed litters of beech and hornbeam were collected from a sample plot of $1 \times 1 \mathrm{~m}$ established under the pure stands of these species, transported to the laboratory, air-dried [46], re-weighed in each sample plot and applied to the mulch plots. Weed free rice straw mulch was applied at three levels, 3.8 (SM3.8), 7.6 (SM7.6) and 11.4 (SM11.4) $\mathrm{Mg} \mathrm{ha}^{-1}$, with $100 \%$ coverage on the skid trail. Rice straws averaged $4-17 \mathrm{~cm}$ in length and $4-6 \mathrm{~mm}$ in thickness [25]. The sawdust mulch treatment consisted of hardwood sawdust (beech and hornbeam) manually spread on the surface plot at three levels, 11.1 (SDM11.1), 22.2 (SDM22.2) and 33.3 (SDM33.3) $\mathrm{Mg} \mathrm{ha}^{-1}$, with diameters ranging from 1 to $5 \mathrm{~mm}$ and lengths from 0.4 to $8 \mathrm{~cm}$. The sawdust used as mulch in this study was obtained from 
sawn-lumber processing residues using chainsaws in the study area. Wire mesh was installed over the top of all plots to capture autumn leaf fall.

Two years after the implementation of the sample plots and mulching (September 2019), soil samples were collected from each plot randomly in three locations at the beginning, middle and end of each plot (for every two meters of sample length) and at two depths of $0-5$ and $5-10 \mathrm{~cm}$. They were then transported to the laboratory to investigate the effect of different treatments on the restoration of soil properties. The same procedure was conducted for sampling in the untreated skid trails (UNT) and the undisturbed (control) area (UND). A total of 198 soil samples (i.e., 3 mulch types $\times 3$ application levels $\times$ 3 replicates $\times 3$ soil samples $\times 2$ soil depths +2 references $($ UNT and UND) $\times 3$ replicates $\times 3$ soil samples $\times 2$ soil depths) were collected and analyzed.

\subsection{Data Collection and Laboratory Analysis}

To determine the soil bulk density and water content, a steel cylinder $50 \mathrm{~mm}$ long and $56 \mathrm{~mm}$ in diameter was used to take soil samples at two depths, $0-5$ and 5-10 cm in each sample point, and then the soil cores were weighed, stored in bags, labelled, transported to the lab, oven-dried to a constant mass at $105^{\circ} \mathrm{C}$ for $24 \mathrm{~h}$. More soil samples were collected from an area of $20 \times 20 \times 5 \mathrm{~cm}$ at each depth, air-dried and passed through a 2-mm sieve to measure the other soil physical and chemical properties. The hydrometer method was conducted to measure the soil particle size distribution [47]. To measure the macroporosity, the water desorption method was applied [48]. To determine the soil penetration resistance (PR), the hand-held soil penetrometer (Eijkelkamp 06.01.SA penetrometer with a $60^{\circ}$ cone) was used. PR was measured at two soil depths: soil surface $(1 \mathrm{~cm}$ depth) representative of surface soil PR value, and $6 \mathrm{~cm}$ depth representative of subsoil PR value. To measure the aggregate stability, the wet sieving procedure was conducted [49]. To measure the soil particle density, the ASTM D854-00 2000 standard was applied, and then Equation (1) was employed to calculate total porosity as follows:

$$
\mathrm{TP}=1-\frac{\frac{\mathrm{M}_{\mathrm{s}}}{\mathrm{VC}}}{2.65} \times 100
$$

where TP is the apparent total porosity (\%), Ms is mass of soil (g), VC is the volume of the intact soil cores $\left(123.10 \mathrm{~cm}^{3}\right)$ and $2.65\left(\mathrm{~g} \mathrm{~cm}^{-3}\right)$ is the particle density.

The Orion Ionalyzer (Model 901) $\mathrm{pH}$ meter was employed to measure soil $\mathrm{pH}$ in a soil:water ratio of 1:2.5. To measure soil organic $C$, the Walkley-Black technique was used [50]. The Kjeldahl method was employed to measure soil total N [51]. Soil C and N storage at depth of $0-5$ and $5-10 \mathrm{~cm}$ was measured as Equation (2):

$$
\mathrm{SO}(\mathrm{C} \text { or } \mathrm{N}) \mathrm{s}=\mathrm{C} \text { or } \mathrm{N} \times \mathrm{BD} \times \mathrm{e} \times 0.1
$$

where: the $\mathrm{SO}(\mathrm{C}$ or $\mathrm{N})$ s indicates the organic $\mathrm{C}$ or $\mathrm{N}$ storage at soil $\left(\mathrm{Mg} \mathrm{ha}^{-1}\right) ; \mathrm{C}$ or $\mathrm{N}$ is the organic $\mathrm{C}$ or $\mathrm{N}$ content $\left(\mathrm{g} \mathrm{kg}^{-1}\right)$; $\mathrm{BD}$ is the bulk density $\left(\mathrm{g} \mathrm{cm}^{-3}\right)$; $\mathrm{e}$ is the thickness of the layers $(\mathrm{cm})$, and 0.1 is a depth conversion factor.

To determine the available phosphorous $(\mathrm{P})$, the Olsen method with a spectrophotometer was used. By using an atomic absorption spectrophotometer, the available potassium $(\mathrm{K})$, calcium $(\mathrm{Ca})$ and magnesium $(\mathrm{Mg})$ (by ammonium acetate extraction at $\mathrm{pH}$ 9) were determined [52].

\subsection{Statistical Analyses}

The effects of different treatments and soil depth on the recovery of soil physical and chemical properties, compared to untreated (UNT) and undisturbed treatments (UND) were examined with a complete block design. The normal data distribution and the homogeneity of variance were tested by the Kolmogorov-Smirnov test and the Levene's test, respectively. Two-way analysis of variance (ANOVA) was applied to compare the restoration of soil physical and chemical properties among litter mulch (LM6.2, LM12.2, LM18.6), 
straw mulch (SM3.8, SM7.6, SM11.4), sawdust mulch (SDM11.1, SDM22.2, SDM33.3), UND and UNT. If the ANOVA detected any significant differences among treatments, the Tukey's test was applied as a post hoc for the treatment group means at $P \leq 0.05$. The relationship between treatments, depth and physico-chemical properties was tested by the Pearson correlation. Non-Metric Multidimensional Scaling (nMDS) was applied to assess the differences in the average soil parameters for the different treatments. The SPSS (release 17.0; New York, NY, USA) statistical package was employed to perform all statistical analyses.

\section{Results}

Soil physical and chemical properties (with the exception of clay, silt and sand) were significantly different among treatments $(P \leq 0.001$; Table 1$)$. Soil physical and chemical properties (with the exception of penetration resistance, $\mathrm{pH}, \mathrm{C}$ and $\mathrm{C}$ storage) were significantly different between two depths $(P \leq 0.05)$, and only available $\mathrm{P}, \mathrm{K}$ and $\mathrm{Mg}$ were significantly different among the interaction effect of treatment $\times$ depth $(P \leq 0.05$; Table 1$)$.

Table 1. Results of ANOVA for the effect of treatment, soil depth and their interaction on soil physical and chemical properties.

\begin{tabular}{|c|c|c|c|c|c|c|c|c|c|}
\hline \multirow{2}{*}{ Parameter } & \multicolumn{3}{|c|}{ df } & \multicolumn{3}{|c|}{$F$} & \multicolumn{3}{|c|}{$P$ Value } \\
\hline & Treat & Depth & Treat $\times$ Depth & Treat & Depth & Treat $\times$ Depth & Treat & Depth & Treat $\times$ Depth \\
\hline $\begin{array}{l}\text { Bulk density } \\
\qquad\left(\mathrm{g} \mathrm{cm}^{-3}\right)\end{array}$ & 10 & 1 & 10 & 27.81 & 4.86 & 0.08 & $0.00^{* *}$ & $0.03^{*}$ & $1^{\text {ns }}$ \\
\hline Total porosity (\%) & 10 & 1 & 10 & 22.48 & 3.94 & 0.1 & $0.00^{* *}$ & $0.05^{*}$ & $1^{\mathrm{ns}}$ \\
\hline $\begin{array}{l}\text { Penetration } \\
\text { resistance }(\mathrm{MPa})\end{array}$ & 10 & 1 & 10 & 62.19 & 3.35 & 0.06 & $0.00^{* *}$ & $0.07^{\mathrm{ns}}$ & $1^{\text {ns }}$ \\
\hline $\begin{array}{l}\text { Aggregate } \\
\text { stability }(\%)\end{array}$ & 10 & 1 & 10 & 245.08 & 15.63 & 0.53 & $0.00^{* *}$ & $0.00^{* *}$ & $0.87^{\mathrm{ns}}$ \\
\hline Clay (\%) & 10 & 1 & 10 & 1.3 & 7.91 & 0.63 & $0.24^{\mathrm{ns}}$ & $0.01^{*}$ & $0.79^{\mathrm{ns}}$ \\
\hline Silt $(\%)$ & 10 & 1 & 10 & 0.74 & 26.34 & 0.49 & $0.69^{\mathrm{ns}}$ & $0.00^{* *}$ & $0.90^{\mathrm{ns}}$ \\
\hline Sand (\%) & 10 & 1 & 10 & 0.59 & 24.42 & 0.57 & $0.82^{\mathrm{ns}}$ & $0.00^{* *}$ & $0.84^{\mathrm{ns}}$ \\
\hline $\mathrm{pH}\left(1: 2.5 \mathrm{H}_{2} \mathrm{O}\right)$ & 10 & 1 & 10 & 27.52 & 1.43 & 0.47 & $0.00^{* *}$ & $0.23^{\mathrm{ns}}$ & $0.91^{\mathrm{ns}}$ \\
\hline $\mathrm{C}(\%)$ & 10 & 1 & 10 & 7.35 & 2.08 & 0.01 & $0.00^{* *}$ & $0.15^{\mathrm{ns}}$ & $1^{\mathrm{ns}}$ \\
\hline N (\%) & 10 & 1 & 10 & 21.49 & 48.38 & 1.16 & $0.00^{* *}$ & $0.00^{* *}$ & $0.32^{\mathrm{ns}}$ \\
\hline $\mathrm{C} / \mathrm{N}$ ratio & 10 & 1 & 10 & 6.96 & 8.39 & 0.47 & $0.00^{* *}$ & $0.00^{* *}$ & $0.91^{\mathrm{ns}}$ \\
\hline $\begin{array}{l}\text { C storage } \\
\left(\mathrm{Mg} \mathrm{ha}^{-1}\right)\end{array}$ & 10 & 1 & 10 & 7.12 & 0.43 & 0.04 & $0.00^{* *}$ & $0.51^{\mathrm{ns}}$ & $1^{\mathrm{ns}}$ \\
\hline $\begin{array}{l}\text { N storage }(\mathrm{Mg} \\
\left.\text { ha }^{-1}\right)\end{array}$ & 10 & 1 & 10 & 10.1 & 36.49 & 0.67 & $0.00^{* *}$ & $0.00^{* *}$ & $0.76^{\mathrm{ns}}$ \\
\hline $\begin{array}{c}\text { Available P } \\
\left(\mathrm{mg} \mathrm{kg}^{-1}\right)\end{array}$ & 10 & 1 & 10 & 401.74 & 753.46 & 2.15 & $0.00^{* *}$ & $0.00^{* *}$ & $0.02^{*}$ \\
\hline $\begin{array}{l}\text { Available K } \\
\left(\mathrm{mg} \mathrm{kg}^{-1}\right)\end{array}$ & 10 & 1 & 10 & 936.16 & 133.87 & 7.02 & $0.00^{* *}$ & $0.00^{* *}$ & $0.00^{* *}$ \\
\hline $\begin{array}{l}\text { Available Ca } \\
\left(\mathrm{mg} \mathrm{kg}^{-1}\right)\end{array}$ & 10 & 1 & 10 & 681 & 56.09 & 1.64 & $0.00^{* *}$ & $0.00^{* *}$ & $0.10^{\mathrm{ns}}$ \\
\hline $\begin{array}{l}\text { Available } \mathrm{Mg} \\
\left(\mathrm{mg} \mathrm{kg}^{-1}\right)\end{array}$ & 10 & 1 & 10 & 247.49 & 73.33 & 2.95 & $0.00^{* *}$ & $0.00^{* *}$ & $0.00^{* *}$ \\
\hline
\end{tabular}

Note: ${ }^{*} P<0.05 ;^{* *} P<0.01 ;{ }^{\text {ns }}$ : Not significant.

At two soil depths, the soil bulk density and penetration resistance were at the highest level in the UNT followed by SDM11.1, whereas the lowest soil bulk density and penetration resistance was detected on UND followed by LM18.6. The soil bulk density was still higher in the UNT than in the UND by $51 \%$ within 2 years after mulching. Total porosity and aggregate stability were significantly higher in the UND followed by LM18.6, whereas the lowest total porosity and aggregate stability was detected under the UNT (Table 2). The highest level of restoration in soil physical properties such as soil bulk density, total porosity, penetration resistance and aggregate stability was observed on 
LM18.6 followed by LM12.2 and LM6.2, whereas the lowest level of restoration of soil physical properties was detected on SDM11.1 followed by SDM22.2 (Table 2).

Soil $\mathrm{pH}$ was at the highest level in UND followed by LM18.6 $\approx$ LM12.2 > LM6.2, whereas the lowest $\mathrm{pH}$ was measured at the UNT followed by SDM22.2 > SDM11.1. Soil organic $C$ was at the highest level in the UND followed by SDM22.2 $\approx$ SDM11.1, whereas the lowest organic $C$ was determined in the UNT followed by LM6.2. The highest values of $C$ storage were found in SDM33.3 followed by SDM22.2, whilst the lowest values of $C$ storage were measured under the LM18.6. Soil total $\mathrm{N}$ and available nutrients (i.e., P, K, Ca and $\mathrm{Mg}$ ) were at the highest level in UND followed by LM18.6 $\approx$ LM12.2, and the lowest in UNT followed by SDM33.3 $\approx \mathrm{SDM} 22.2$. Significantly the highest soil C/N ratio was found under the UNT followed by SDM33.3, and the lowest under the LM18.6 $\approx$ LM12.2 followed by LM6.2 > UND. Soil N storage was the highest level at the LM18.6 $\approx$ LM12.2, and the lowest under UNT followed by SDM33.3 (Table 3).

The restoration values of soil physical and chemical properties were at the highest level under the LM18.6 followed by LM12.2 $\approx$ LM6.2, and the lowest level under the $\mathrm{SDM} 33.3 \approx \mathrm{SDM} 22.2$ followed by SDM11.1, as compared to the UNT, but the restoration values of soil physical and chemical properties were still lower than the UND.

By increasing the application rate at three mulches (i.e., litter, straw and sawdust), the restoration values of soil physical properties were increased. The restoration values of soil chemical properties were increased as the application rate of litter mulch increased, however the inverse trends were observed under the straw and sawdust mulch treatment.

Treatments significantly and positively correlated with soil bulk density, penetration resistance, $\mathrm{C} / \mathrm{N}$ ratio, $\mathrm{C}$ storage and negatively correlated with total porosity, aggregate stability, $\mathrm{pH}$, soil $\mathrm{N}$, soil C, N storage and available nutrients ( $\mathrm{P}, \mathrm{K}, \mathrm{Ca}$ and $\mathrm{Mg}$ ). Soil bulk density significantly and positively correlated with soil penetration resistance, $\mathrm{C} / \mathrm{N}$ ratio, $\mathrm{C}$ storage and negatively correlated with aggregate stability, $\mathrm{pH}$, soil $\mathrm{N}, \mathrm{N}$ storage and available nutrients (P, K, Ca and $\mathrm{Mg}$ ) (Table 4).

Principal non-metric multidimensional scaling (nMDS) tests produced a two-dimensional ordination that provided a significantly greater reduction in statistical stress than expected by chance ( $\alpha<0.05$ for both soil layers, Figures 2 and 3). When considering soil bulk density, penetration resistance, $\mathrm{C} / \mathrm{N}$ ratio, $\mathrm{C}$ storage, total porosity, aggregate stability, $\mathrm{pH}$, soil $\mathrm{N}$, soil $\mathrm{C}, \mathrm{N}$ storage and available nutrients $(\mathrm{P}, \mathrm{K}, \mathrm{Ca}$ and $\mathrm{Mg}$ ), the two axes explained $98.1 \%$ of the overall variance of the litter type variables only for the soil layer $0-5 \mathrm{~cm}$ (Figure 2) and $96.7 \%$ for the $5-10 \mathrm{~cm}$ soil layer (Figure 3).

For both soil layers studied, the variables soil bulk density, penetration resistance, total porosity, aggregate stability, $\mathrm{pH}$, soil $\mathrm{N}, \mathrm{N}$ storage and available nutrients $(\mathrm{P}, \mathrm{K}, \mathrm{Ca}$ and $\mathrm{Mg}$ ) are more related to the weighed scale of axis 1 (Figures 2 and 3). Always for both soil layers studied, the scenario along axis 2 was dominated by the $\mathrm{C} / \mathrm{N}$ ratio, $\mathrm{C}$ storage and soil $C$ variables (Figures 2 and 3 ). In both soil layers studied, the nMDS for the three mulching treatments (Figures 2 and 3) showed the better soil recovery condition close to the UND (undisturbed soil) in the LM treatments (with a positive trend related to the mulching amount), followed by SM treatments and the worst soil recovery condition, very close to UNT (untreated soil) in the SDM treatments (Figures 2 and 3). 


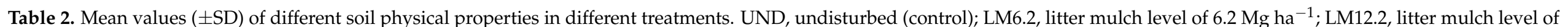

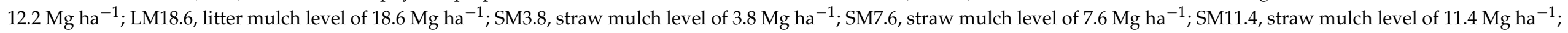

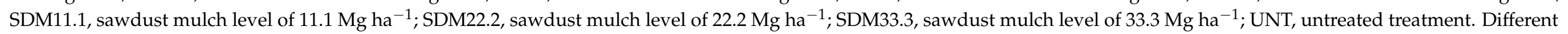

letters after means within each treatment indicate significant differences by Tukey's test $(P<0.05)$.

\begin{tabular}{|c|c|c|c|c|c|c|c|c|c|c|c|c|}
\hline \multirow{2}{*}{ Soil Properties } & \multirow{2}{*}{$\begin{array}{l}\text { Depth } \\
\text { (cm) }\end{array}$} & \multicolumn{11}{|c|}{ Treatment } \\
\hline & & UND & LM6.2 & LM12.2 & LM18.6 & SM3.8 & SM7.6 & SM11.4 & SDM11.1 & SDM22.2 & SDM33.3 & UNT \\
\hline $\begin{array}{l}\text { Bulk density } \\
\left(\mathrm{g} \mathrm{cm}^{-3}\right)\end{array}$ & $0-5$ & $0.87 \pm 0.09 \mathrm{~d}$ & $1.12 \pm 0.11 b c$ & $1.09 \pm 0.1 b c$ & $1.03 \pm 0.07 \mathrm{~cd}$ & $1.23 \pm 0.08 \mathrm{ab}$ & $1.21 \pm 0.12 \mathrm{ab}$ & $\begin{array}{c}1.18 \pm \\
0.09 \mathrm{abc}\end{array}$ & $1.28 \pm 0.13 a$ & $1.24 \pm 0.09 \mathrm{ab}$ & $1.25 \pm 0.11 \mathrm{ab}$ & $1.31 \pm 0.12 a$ \\
\hline \multirow{2}{*}{$\begin{array}{c}\text { Total porosity } \\
(\%)\end{array}$} & $0-5$ & $64.14 \pm 3.65 \mathrm{a}$ & $55.93 \pm 4.29 b c$ & $\begin{array}{c}57.02 \pm \\
3.67 \mathrm{bc}\end{array}$ & $59.7 \pm 2.86 \mathrm{ab}$ & $\begin{array}{l}51.94 \pm \\
2.96 \mathrm{cde}\end{array}$ & $\begin{array}{l}52.18 \pm \\
4.64 \mathrm{cde}\end{array}$ & $53.9 \pm 3.59 b c$ & $\begin{array}{c}49.84 \pm \\
5.45 \mathrm{de}\end{array}$ & $\begin{array}{l}51.26 \pm \\
3.88 \mathrm{cde}\end{array}$ & $\begin{array}{l}51.07 \pm \\
4.27 \mathrm{cde}\end{array}$ & $48.83 \pm 4.74 \mathrm{e}$ \\
\hline & $5-10$ & $62.69 \pm 3.67 \mathrm{a}$ & $54.47 \pm 5.62 \mathrm{bcd}$ & $\begin{array}{c}55.89 \pm \\
3.19 \mathrm{bc}\end{array}$ & $\begin{array}{c}57.63 \pm \\
2.25 \mathrm{ab}\end{array}$ & $\begin{array}{l}51.2 \pm \\
5.04 \mathrm{cde}\end{array}$ & $\begin{array}{l}52.33 \pm \\
3.09 \mathrm{bcd}\end{array}$ & $\begin{array}{l}52.76 \pm \\
3.45 \mathrm{bcd}\end{array}$ & $48.69 \pm 4.5 \mathrm{de}$ & $\begin{array}{l}50.8 \pm \\
4.49 \mathrm{cde}\end{array}$ & $\begin{array}{c}49.54 \pm \\
2.78 \mathrm{de}\end{array}$ & $47.22 \pm 5.08 \mathrm{e}$ \\
\hline $\begin{array}{l}\text { Penetration } \\
\text { resistance } \\
(\mathrm{MPa})\end{array}$ & $0-5$ & $0.88 \pm 0.12 \mathrm{~g}$ & $1.6 \pm 0.21 \mathrm{ef}$ & $1.51 \pm 0.26 \mathrm{ef}$ & $1.29 \pm 0.18 f$ & $1.98 \pm 0.16 \mathrm{~cd}$ & $1.91 \pm 0.21 \mathrm{~cd}$ & $1.75 \pm 0.24 \mathrm{de}$ & $2.18 \pm 0.3 \mathrm{ab}$ & $2.1 \pm 0.26 \mathrm{abc}$ & $1.95 \pm 0.23 \mathrm{~cd}$ & $2.38 \pm 0.25 a$ \\
\hline \multirow{2}{*}{$\begin{array}{l}\text { Aggregate } \\
\text { stability (\%) }\end{array}$} & $0-5$ & $59.2 \pm 9.2 \mathrm{a}$ & $42.25 \pm 2.69 \mathrm{bc}$ & $46.01 \pm 1.71 b$ & $47.1 \pm 1.73 b$ & $\begin{array}{l}37.51 \pm \\
1.54 \mathrm{~cd}\end{array}$ & $\begin{array}{l}36.12 \pm \\
1.46 \mathrm{de}\end{array}$ & $\begin{array}{l}34.31 \pm \\
1.72 \mathrm{de}\end{array}$ & $\begin{array}{c}31.69 \pm \\
1.48 \mathrm{ef}\end{array}$ & $29.03 \pm 1.68 \mathrm{f}$ & $28.1 .5963 \pm f$ & $21.53 \pm 2.2 \mathrm{~g}$ \\
\hline & $5-10$ & $55.84 \pm 2.9 a$ & $39.28 \pm 3.56 c$ & $43.7 \pm 1.8 \mathrm{~b}$ & $45.72 \pm 0.98 b$ & $\begin{array}{c}36.34 \pm \\
1.52 \mathrm{~cd}\end{array}$ & $34.62 \pm 0.89 \mathrm{~d}$ & $\begin{array}{c}34.14 \pm \\
2.36 \mathrm{de}\end{array}$ & $30.86 \pm 2.7 \mathrm{ef}$ & $\begin{array}{c}28.02 \pm \\
1.55 \mathrm{fg}\end{array}$ & $27.51 \pm 1.53 \mathrm{~g}$ & $20.29 \pm 2.05 h$ \\
\hline \multirow{3}{*}{ Clay (\%) } & $0-5$ & $20.0 \pm 3.8 \mathrm{a}$ & $18.22 \pm 3.5 \mathrm{a}$ & $24.23 \pm 5.8 \mathrm{a}$ & $19.56 \pm 5.1 \mathrm{a}$ & $23.11 \pm 3.9 \mathrm{a}$ & $24.78 \pm 7.8 \mathrm{a}$ & $22.16 \pm 5.7 a$ & $21.99 \pm 4.1 \mathrm{a}$ & $22.46 \pm 4.7 \mathrm{a}$ & $25.27 \pm 7.7 \mathrm{a}$ & $20.0 \pm 2.5 a$ \\
\hline & $5-10$ & $25.01 \pm 5.2 \mathrm{a}$ & $22.56 \pm 5.1 \mathrm{a}$ & $26.92 \pm 6.2 \mathrm{a}$ & $25.11 \pm 9.6 \mathrm{a}$ & $23.29 \pm 7.3 a$ & $24.44 \pm 6.8 \mathrm{a}$ & $23.11 \pm 6.1 \mathrm{a}$ & $23.38 \pm 4.3 \mathrm{a}$ & $25.37 \pm 5.8 \mathrm{a}$ & $24.67 \pm 4.0 \mathrm{a}$ & $23.11 \pm 5.9 \mathrm{a}$ \\
\hline & $0-5$ & $24.0 \pm 6.0 \mathrm{a}$ & $25.56 \pm 11.8 \mathrm{a}$ & $23.67 \pm 7.3 a$ & $20.22 \pm 6.1 \mathrm{a}$ & $23.33 \pm 7.2 \mathrm{a}$ & $24.94 \pm 5.1 \mathrm{a}$ & $25.87 \pm 11.1 \mathrm{a}$ & $23.92 \pm 4.8 \mathrm{a}$ & $24.4 \pm 5.7 \mathrm{a}$ & $27.92 \pm 13.8 a$ & $26.67 \pm 4.5 a$ \\
\hline \multirow[t]{2}{*}{ Silt (\%) } & $5-10$ & $32.56 \pm 4.6 \mathrm{a}$ & $30.33 \pm 5.2 \mathrm{a}$ & $27.37 \pm 8.4 a$ & $29.11 \pm 8.7 \mathrm{a}$ & $31.52 \pm 8.8 \mathrm{a}$ & $32.0 \pm 6.1 \mathrm{a}$ & $30.44 \pm 9.1 \mathrm{a}$ & $26.42 \pm 5.8 \mathrm{a}$ & $31.59 \pm 8.8 \mathrm{a}$ & $29.11 \pm 7.8 \mathrm{a}$ & $32.22 \pm 4.9 \mathrm{a}$ \\
\hline & $0-5$ & $56.0 \pm 9.4 a$ & $56.22 \pm 12.9 a$ & $52.1 \pm 10.8 \mathrm{a}$ & $60.22 \pm 10.5 a$ & $53.56 \pm 9.8 \mathrm{a}$ & $50.28 \pm 11.7 \mathrm{a}$ & $51.98 \pm 14.2 \mathrm{a}$ & $54.09 \pm 5.6 \mathrm{a}$ & $53.14 \pm 6.8 \mathrm{a}$ & $46.81 \pm 19.8 a$ & $53.33 \pm 5.6 a$ \\
\hline
\end{tabular}




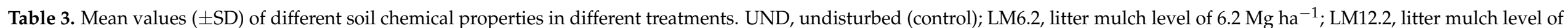

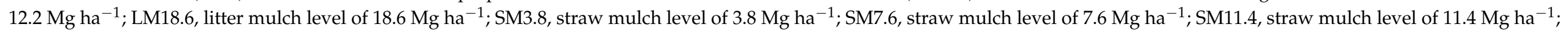

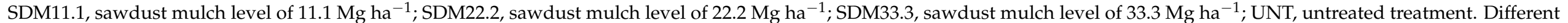
letters after means within each treatment indicate significant differences by Tukey's test $(P<0.05)$.

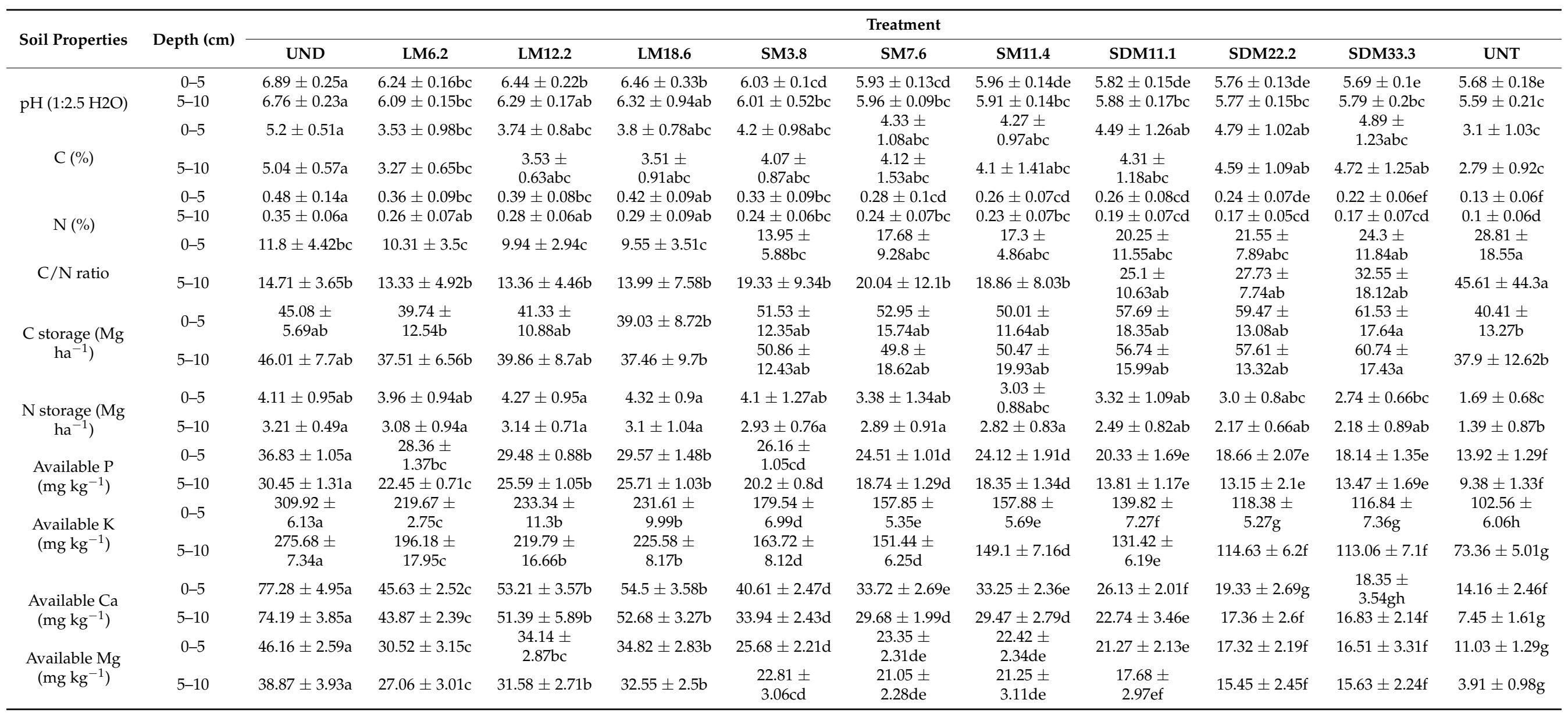




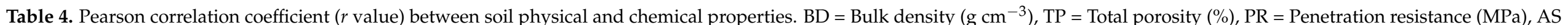

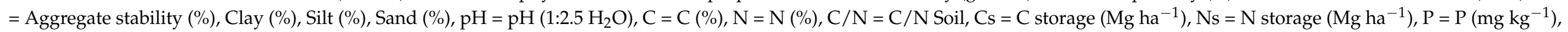

$\mathrm{K}=\mathrm{K}\left(\mathrm{mg} \mathrm{kg}^{-1}\right), \mathrm{Ca}=\mathrm{Ca}\left(\mathrm{mg} \mathrm{kg}^{-1}\right), \mathrm{Mg}=\mathrm{Mg}\left(\mathrm{mg} \mathrm{kg}^{-1}\right)$. Note: ${ }^{*} P<0.05 ;^{* *} P<0.01$.

\begin{tabular}{|c|c|c|c|c|c|c|c|c|c|c|c|c|c|c|c|c|c|c|}
\hline Parameters & Depth & BD & TP & PR & AS & Clay & Silt & Sand & $\mathrm{pH}$ & $\mathrm{C}$ & $\mathbf{N}$ & $\mathrm{C} / \mathrm{N}$ & Cs & Ns & $\mathbf{P}$ & $\mathbf{K}$ & $\mathrm{Ca}$ & Mg \\
\hline Treat & 0.00 & $0.66^{* *}$ & $-0.64^{* *}$ & $0.76^{* *}$ & $-0.89^{* *}$ & 0.04 & 0.06 & -0.06 & $-0.71^{* *}$ & -0.01 & $-0.65^{* *}$ & $0.48^{* *}$ & $0.28^{* *}$ & $-0.51^{* *}$ & $-0.87^{* *}$ & $-0.93^{* *}$ & $-0.92^{* *}$ & $-0.89^{* *}$ \\
\hline Depth & & 0.10 & -0.09 & 0.07 & -0.08 & $0.19^{* *}$ & $0.35^{* *}$ & $-0.34^{* *}$ & -0.06 & -0.09 & $-0.33^{* *}$ & $0.18^{*}$ & -0.04 & $-0.34^{* *}$ & $-0.39^{* *}$ & -0.12 & -0.09 & $-0.16^{*}$ \\
\hline $\mathrm{BD}$ & & & $-0.99^{* *}$ & 0.72 ** & $-0.72^{* *}$ & 0.03 & 0.08 & -0.07 & $-0.56^{* *}$ & -0.09 & $-0.58^{* *}$ & $0.39^{* *}$ & $0.36^{* *}$ & $-0.28^{* *}$ & $-0.70^{* *}$ & $-0.75^{* *}$ & $-0.75^{* *}$ & $-0.70^{* *}$ \\
\hline $\mathrm{TP}$ & & & & $-0.69^{* *}$ & $0.69^{* *}$ & -0.04 & -0.08 & 0.07 & $0.52^{* *}$ & 0.06 & $0.58^{* *}$ & $-0.42^{* *}$ & $-0.38^{* *}$ & $0.29^{* *}$ & $0.68^{* *}$ & $0.72^{* *}$ & $0.73^{* *}$ & $0.68^{* *}$ \\
\hline PR & & & & & $-0.79^{* *}$ & 0.08 & 0.11 & -0.11 & $-0.66^{* *}$ & -0.11 & $-0.58^{* *}$ & $0.39^{* *}$ & $0.22^{* *}$ & $-0.39^{* *}$ & $-0.77^{* *}$ & $-0.84^{* *}$ & $-0.83^{* *}$ & $-0.79^{* *}$ \\
\hline AS & & & & & & -0.02 & -0.08 & 0.06 & $0.75^{* *}$ & 0.13 & $0.67^{* *}$ & $-0.42^{* *}$ & $-0.21^{* *}$ & $0.48^{* *}$ & $0.89^{* *}$ & $0.95^{* *}$ & $0.96^{* *}$ & $0.95^{* *}$ \\
\hline Clay & & & & & & & $0.41^{* *}$ & $-0.78^{* *}$ & -0.09 & -0.02 & -0.10 & 0.07 & -0.00 & -0.08 & -0.07 & -0.07 & -0.04 & -0.03 \\
\hline Silt & & & & & & & & $-0.89^{* *}$ & $-0.16^{*}$ & 0.00 & $-0.18^{* *}$ & 0.12 & 0.03 & $-0.18^{*}$ & $-0.17^{*}$ & -0.11 & -0.09 & -0.12 \\
\hline Sand & & & & & & & & & $0.16^{*}$ & 0.01 & $0.18^{*}$ & -0.12 & -0.02 & $0.17^{*}$ & $0.15^{*}$ & 0.11 & 0.08 & 0.09 \\
\hline C & & & & & & & & & & & 0.04 & $0.26^{* *}$ & $0.88^{* *}$ & 0.00 & 0.13 & 0.09 & 0.09 & 0.13 \\
\hline $\mathrm{N}$ & & & & & & & & & & & & $-0.65^{* *}$ & $-0.23^{* *}$ & $0.92^{* *}$ & $0.73^{* *}$ & $0.70^{* *}$ & $0.69^{* *}$ & $0.69^{* *}$ \\
\hline $\mathrm{CN}$ & & & & & & & & & & & & & $0.42^{* *}$ & $-0.67^{* *}$ & $-0.46^{* *}$ & $-0.45^{* *}$ & $-0.46^{* *}$ & $-0.46^{* *}$ \\
\hline Cs & & & & & & & & & & & & & & -0.12 & $-0.19^{* *}$ & $-0.26^{* *}$ & $-0.26^{* *}$ & $-0.19^{* *}$ \\
\hline Ns & & & & & & & & & & & & & & & $0.57^{* *}$ & $0.51^{* *}$ & $0.49^{* *}$ & $0.52^{* *}$ \\
\hline $\mathrm{P}$ & & & & & & & & & & & & & & & & $0.92^{* *}$ & $0.91^{* *}$ & $0.91^{* *}$ \\
\hline $\mathrm{K}$ & & & & & & & & & & & & & & & & & $0.97^{* *}$ & $0.94^{* *}$ \\
\hline $\mathrm{Ca}$ & & & & & & & & & & & & & & & & & & $0.95^{* *}$ \\
\hline
\end{tabular}




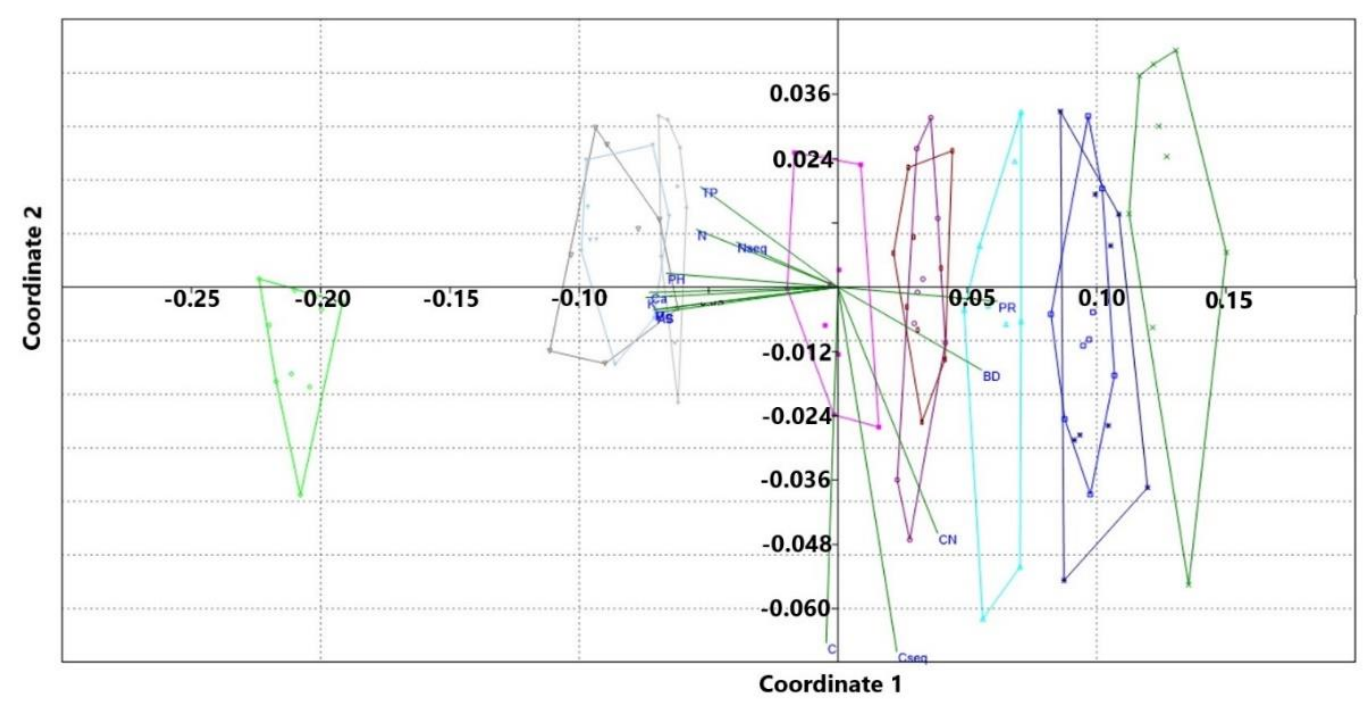

Figure 2. nMDS analysis of different soil physical properties in different mulching or no-mulching treatments for the soil layer 0-5 cm. UND, undisturbed (control), light green polygon; LM6.2, litter mulch level of $6.2 \mathrm{Mg}^{-1}$, light grey polygon; LM12.2, litter mulch level of $12.2 \mathrm{Mg} \mathrm{ha}^{-1}$, dark grey polygon; LM18.6, litter mulch level of $18.6 \mathrm{Mg} \mathrm{ha}^{-1}$, light blue polygon; SM3.8, straw mulch level of $3.8 \mathrm{Mg} \mathrm{ha}^{-1}$, light purple polygon; SM7.6, straw mulch level of $7.6 \mathrm{Mg} \mathrm{ha}^{-1}$, dark purple polygon; SM11.4, straw mulch level of $11.4 \mathrm{Mg} \mathrm{ha}^{-1}$, red polygon; SDM11.1, sawdust mulch level of $11.1 \mathrm{Mg}^{-1}$, bright light blue polygon; SDM22.2, sawdust mulch level of $22.2 \mathrm{Mg} \mathrm{ha}^{-1}$, blue polygon; SDM33.3, sawdust mulch level of 33.3 $\mathrm{Mg} \mathrm{ha}^{-1}$, dark blue polygon; UNT, untreated treatment, dark green polygon.

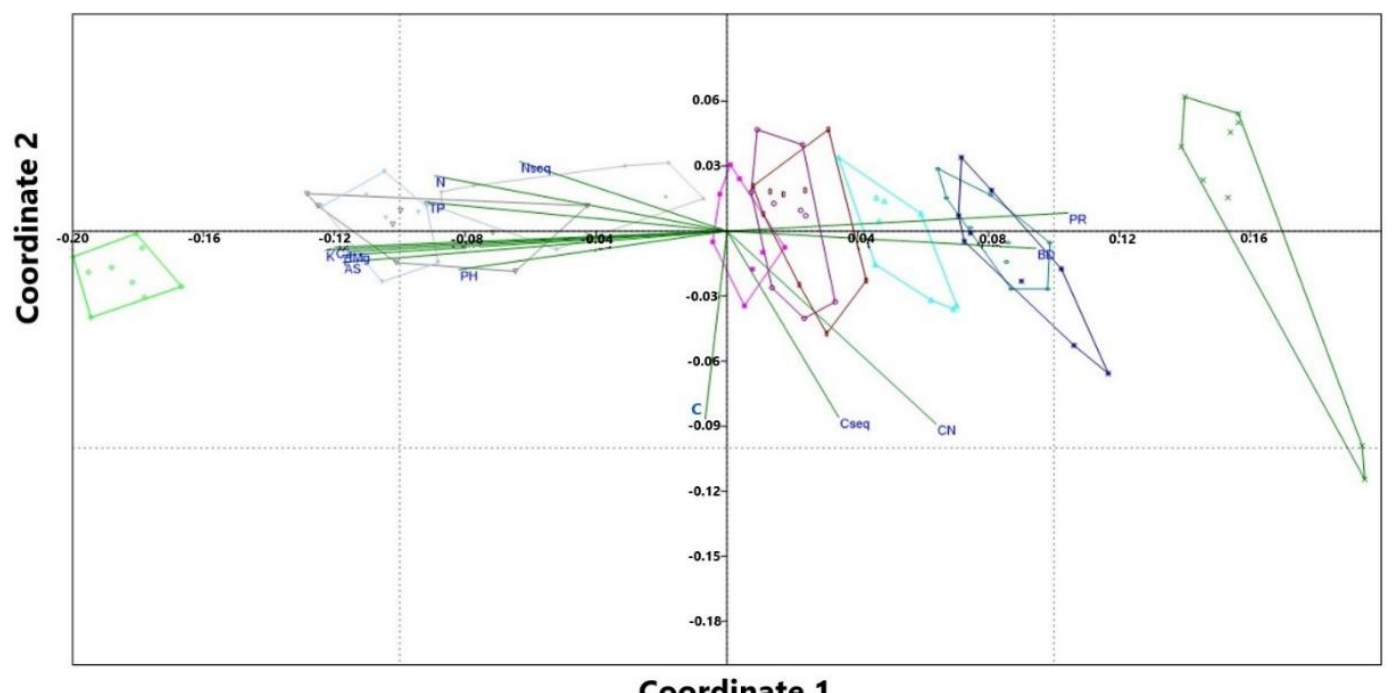

Figure 3. nMDS analysis of different soil physical properties in different mulching or no-mulching treatments for the soil layer 5-10 cm. UND, undisturbed (control), light green polygon; LM6.2, litter mulch level of $6.2 \mathrm{Mg} \mathrm{ha}^{-1}$, light grey polygon; LM12.2, litter mulch level of $12.2 \mathrm{Mg} \mathrm{ha}^{-1}$, dark grey polygon; LM18.6, litter mulch level of $18.6 \mathrm{Mg}^{-1}$, light blue polygon; SM3.8, straw mulch level of $3.8 \mathrm{Mg} \mathrm{ha}^{-1}$, light purple polygon; SM7.6, straw mulch level of $7.6 \mathrm{Mg}^{-1}$, dark purple polygon; SM11.4, straw mulch level of $11.4 \mathrm{Mg} \mathrm{ha}^{-1}$, red polygon; SDM11.1, sawdust mulch level of $11.1 \mathrm{Mg}^{-1}$, bright light blue polygon; SDM22.2, sawdust mulch level of $22.2 \mathrm{Mg}^{-1}$, blue polygon; SDM33.3, sawdust mulch level of 33.3 $\mathrm{Mg} \mathrm{ha}^{-1}$, dark blue polygon; UNT, untreated treatment, dark green polygon.

\section{Discussion}

Comparison of soil bulk density in UNT with control (UND) showed that soil bulk density was still significantly different from UND and after 2 years it was 51\% higher than 
the UND treatment. Forest soils with low bulk density, high porosity and high organic matter content $[5,39]$ are prone to mechanical stress $[20,26]$. Soil compaction due to the traffic of skidders on forest soil, has negative effects on soil aggregates such as increasing soil bulk density [6], reducing total porosity and coarse macroporosity [1], increasing penetration resistance [53] and reducing air permeability [5]. Simultaneously, after the removal of the litter layer, soil chemical properties were changed dramatically, which decreased the available nutrients and $\mathrm{N}$ cycle on the soil layer [54]. Results showed that soil bulk density increased with increasing soil depth from $1.16 \mathrm{~g} \mathrm{~cm}^{-3}$ at a depth of $0-5$ to $1.20 \mathrm{~g} \mathrm{~cm}^{-3}$ at a depth of $5-10 \mathrm{~cm}$, which is consistent with the results of previous findings stating that, soil bulk density increased and porosity decreased as soil depth increased [55].

Results show that soil bulk density in the litter, straw and sawdust mulching treatments had the highest restoration level, respectively, but still had a significant difference with the UND treatment. Furthermore, in all three treatments of litter, straw and sawdust, by increasing the rate of mulch application level, soil bulk density enhanced, but in litter and sawdust treatments, soil bulk density in the second and third levels did not differ significantly. In general, organic mulch can be used on the soil surface to provide cover and protect forest soils [21,56]. As a result, mulch absorbs solar energy, regulates soil temperature and water changes [57,58], and balances gas fluctuations between the atmosphere and soil [31]. As a result of these effects, the use of mulch leads to reduced surface runoff and soil erosion [9]. In line with the results of the current study, Jourgholami et al. [26] showed that soil physical and chemical properties are significantly restored over a period of 5 years after application litter mulch on the vehicle-impacted soil. In addition, Meyer et al. [39] reported that the compost application in wheel tracks on skid trails increased the growth of black alder (Alnus glutinosa (L.) Gaertn.) seedlings and restored soil structure.

Among mulch treatments, litter resulted to have the highest total porosity and sawdust treatment had the lowest total porosity. The results showed that total porosity increased in the two treatments of litter and straw with the increasing mulch application level. In agricultural lands, the addition of mulch can enhance the total porosity [20]. Similarly, Jordán et al. [31] found that soil physical and chemical properties such as soil bulk density, total porosity, aggregate stability and organic matter content were restored after mulch application. In this regard, Flores Fernández et al. [9] concluded that the addition of mulch to the compacted soil surface in the skidding trails significantly accelerated the restoration of soil structure.

The results of the current study showed that the soil penetration resistance was partially recovered in litter, straw and sawdust mulch treatments as compared to UNT treatment but still significantly lower than in the UND even after 2 years from skidding operations. Under natural conditions, the recovery of soil characteristics after skidding machine traffic is a slow process, and a period of time from a few years to several decades is needed to return to the original conditions $[1,3,5]$.

The addition of organic mulch on the surface of soil in the skid trails results in an increase in surface roughness and aggregate stability, absorbs the kinetic energy of raindrops, increases water absorption capacity, enhances water infiltration, which ultimately reduces soil particle detachment, surface runoff and soil loss $[14,59,60]$. In line with the results of the current study, Jordán et al. [31] found that the application of organic mulch enhanced soil hydrological properties, which led to increase soil organic matter, soil aggregates stability and enhance soil aeration, porosity, soil structure and moisture. These ultimately restore soil penetration resistance and physical conditions. In addition, organic mulches retain soil moisture by reducing evaporation [61]. Previous studies reported that the soil moisture content under different mulch treatments was higher than in bare soil that is without mulch [14,31]. Kader et al. [14] reported that the ability of mulch to retain soil moisture is highly dependent on the thickness of the mulch layer applied to the soil surface. Similarly, Ugawa et al. [11] reported that application of organic mulch led to restore soil properties after compaction in the skid trails. An increase in aggregate stability after mulch 
application can be attributed to an increase in organic matter content, which improved the fungal and bacterial activities [26].

Results showed that the type and level of mulching did not have a significant effect on soil texture characteristics two years after skidding operations and mulching. This can be due to the long-lasting process of changes in soil texture and two years is not long enough to restore soil texture.

Decomposition of organic mulches by microbes leads to the addition of nutrients into the soil layer, which plays an important role in carbon sequestration [14]. In general, leaf litter supplies nutrients at higher rates than the straw and sawdust mulches. The higher soil temperature under organic mulches enhances soil microbial activity leading to accelerate the decomposition of organic matter in the soil [2,12]. Kader et al. [14] concluded that there is a close relationship between soil moisture and soil microbial biomass carbon. Organic mulch (e.g., leaf litter, straw and sawdust) can stimulate soil micro-and macro-organisms such as fungi, bacteria and earthworms [3,61-63], which regulate the decomposition of organic matter and nutrient mineralization [12]. Ren et al. [64] determined that surface applied organic mulch results in an increase of total soil nitrogen due to the increase in the nitrogen metabolism. Organic mulches influence on soil physical and chemical properties through changing in soil moisture and temperature conditions $[13,14]$.

Organic mulches such as litter, straw and sawdust control the extreme fluctuations of soil temperature and incorporate organic matter into soil, which augments the microorganisms' activities such as earthworms [65], that help to improve soil structure and nutrient cycling. Following mulch application, organic matter content depletes due to the accelerated biodegradation process imposed by an increase in soil temperature, which led to a decrease in $\mathrm{C} / \mathrm{N}$ ratios [14]. Results show that the $\mathrm{C} / \mathrm{N}$ ratio was higher in straw and sawdust mulch than in litter. Application of the carbon rich mulch such as straw and sawdust leads to the consumption of the nitrogen by microorganisms during the decomposition processes of organic substrates resulting in a nitrogen deficit [66]. Ugawa et al. [11] determined that soil compaction led to the lower concentrations of soil $\mathrm{C}$ and $\mathrm{N}$, compared to the undisturbed area.

Soil compaction after ground-based skidding operations leads to a decrease in soil pore volume and continuity, reduce soil water permeability and increase water retention, which results in a decrease in the soil microbial biomass and the soil $\mathrm{N}$ mineralization rate $[1,67,68]$. Ugawa et al. [11] indicated that the soil $\mathrm{C}$ and $\mathrm{N}$ concentrations enhanced after slash dispersing on the compacted soil. The high soil $\mathrm{C} / \mathrm{N}$ ratio of sawdust mulch can be attributed to the concentrations of recalcitrant compounds such as lignin, which leads to a decrease in the soil organic decomposition and soil $\mathrm{N}$ mineralization [11].

Soil $\mathrm{C}$ and $\mathrm{N}$ concentrations were higher in the litter mulch than in the straw and sawdust mulch, which has a faster decomposition rate than leaf litter. It supplies a higher amount of $\mathrm{N}$ from litter mulch as reported by Ugawa et al. [11]. Organic mulches not only supply soil $\mathrm{C}$ and $\mathrm{N}$ but also mitigate soil bulk density and penetration resistance in the skid trail within 2 years after treatments are applied. The lower amount of $C$ and $\mathrm{N}$ concentrations in the surface soil layer at the UNT can be explained by the erosion of surface soil imposed by the overland flow as reported by Jourgholami et al. [8]. Results of the current study demonstrated that the restoration of available nutrients $(\mathrm{P}, \mathrm{K}, \mathrm{Mg}$ and $\mathrm{Ca})$ was found at the highest level in the litter, which was more than that found in the straw and sawdust treatments. High-quality litter with labile components and low $\mathrm{C} / \mathrm{N}$ ratio plays a key role to supply organic matter content for accelerating the microbial activities [65].

The results showed that litter mulch had a greater effect on the recovery level of soil physical and chemical characteristics than sawdust and straw mulch. In other words, the low lignin to nitrogen ratio and the low $\mathrm{C} / \mathrm{N}$ ratio causes a faster decomposing rate in litter mulch than straw and sawdust, and as a result, the soil fauna populations improve due to increased microbial activities. On the other hand, following the mixing of litter and mineral soil layers, the mulch coating prevents surface erosion and helps to accelerate the restoration process of soil physical and chemical characteristics [26]. The addition of 
sawdust on the soil surface, although it reduces the surface runoff and sediment, leads to an increase in the $\mathrm{C} / \mathrm{N}$ ratio and the acidification of the soil due to high lignin content, which ultimately leads to suppress the recovery of soil properties.

The results of the current study highlight the benefits of the application of organic mulch such as litter, straw and sawdust showing that the organic mulch retained soil moisture and enhanced the soil physical and chemical properties. What is more, the findings of the current study showed that various organic mulches have different effects on soil properties at the two soil depths. The results of previous studies were confirmed, and it was shown that the application of mulch enhanced soil physical and chemical properties after a 2-year period. As this study confirms, the application level of mulch was an effective factor for enhancing soil conditions. The hypothesis of the present study, which states that there is a statistically significant difference between the effects of litter, straw and sawdust mulch treatments on the restoration of soil physical and chemical properties in the skid trails, is supported by the results of this study. However, it is to be acknowledged that full recovery of soil physical and chemical properties in the skid trails treated with organic mulches will take more than two years.

This study did not address the economic aspects of using different mulches and the financial evaluation of management measures for rehabilitation and protection of soil in skid trails. However, if one mulch type was selected according to technical criteria, it must also be evaluated financially to select the optimum recommendation for application in the forest. The use of litter mulch, due to the low costs of preparation and low transportation costs, can be a viable alternative as compared to straw and sawdust mulches. Furthermore, in the case of rice straw, there is a possibility of introducing weed seeds to forest areas [15], which should be considered in the application of this type of mulch. Further research is needed on the efficacy of different organic mulches on soil restorations.

\section{Conclusions}

This study has observed that the use of different levels of organic mulch such as litter, straw and sawdust, in terms of its ability to restore soil physical and chemical properties on skid trails after machine traffic and mulching were evaluated after a 2-year period and compared with the untreated trail (UNT; without mulch) and control area (UND). The key findings are summarized as follows:

- The values of soil physical and chemical properties in litter, straw and sawdust treatments were significantly restored as compared with the values in the UNT but were still different from the values of the control treatment (UND).

- According to the current results, a 2-year period is not enough to return the soil physical and chemical properties to pre-traffic levels (using values measured in the control area or intact as a reference point) and a period of more than 2 years is needed for restoring soil properties.

- The present study shows that organic mulch spread on the surface of mineral soil in the skid trails after machine traffic acts as a fertilizer to accelerate the decomposition of organic matter.

- In general, the litter mulch with application levels of 6.2-12.2 $\mathrm{Mg} \mathrm{ha}^{-1}$, straw mulch with application levels of $3.8-7.6 \mathrm{Mg} \mathrm{ha}^{-1}$ and sawdust mulch with application levels of 22.2-33.3 Mg ha ${ }^{-1}$ can be applied as an optimal level for spreading on skid trails to amend soil quality. 
Author Contributions: Conceptualization, A.K., M.J. (Meghdad Jourgholami) and M.J. (Mohammad Jafari); data curation, A.K., M.J. (Meghdad Jourgholami), M.J. (Mohammad Jafari) and R.V.; formal analysis, A.K., M.J. (Meghdad Jourgholami), M.J. (Mohammad Jafari) and R.P.; investigation, A.K., M.J. (Meghdad Jourgholami) and M.J. (Mohammad Jafari); methodology, A.K., M.J. (Meghdad Jourgholami), M.J. (Mohammad Jafari), R.V. and R.P.; supervision, M.J. (Meghdad Jourgholami), F.T. and R.P.; validation, M.J. (Meghdad Jourgholami), F.T. and R.P.; writing-original draft, A.K., M.J. (Mohammad Jafari), R.V. and R.P.; writing-review and editing, M.J. (Meghdad Jourgholami), F.T. and R.P. All authors have read and agreed to the published version of the manuscript.

Funding: This research received no external funding.

Data Availability Statement: Data available on request from the corresponding author, due to privacy restrictions.

Acknowledgments: This work is part of results of the first author's Ph.D. thesis. The authors would like to acknowledge the support of the Deputy of Research, University of Tehran. This work was supported by the Italian Ministry for education, University and Research (MIUR) for financial support (Law 232/2016, Italian University Departments of excellence)-UNITUS -DAFNE WP3.

Conflicts of Interest: The authors declare no conflict of interest.

\section{References}

1. Picchio, R.; Mederski, P.S.; Tavankar, F. How and How Much, Do Harvesting Activities Affect Forest Soil, Regeneration and Stands? Curr. For. Rep. 2020, 6, 115-128. [CrossRef]

2. Jourgholami, M.; Khoramizadeh, A.; Lo Monaco, A.; Venanzi, R.; Latterini, F.; Tavankar, F.; Picchio, R. Evaluation of leaf litter mulching and incorporation on skid trails for the recovery of soil physico-chemical and biological properties of mixed broadleaved forests. Land 2021, 10, 625. [CrossRef]

3. Sohrabi, H.; Jourgholami, M.; Jafari, M.; Tavankar, F.; Venanzi, R.; Picchio, R. Earthworms as an ecological indicator of soil recovery after mechanized logging operations in mixed beech forests. Forests 2021, 12, 18. [CrossRef]

4. Sohrabi, H.; Jourgholami, M.; Jafari, M.; Shabanian, N.; Venanzi, R.; Tavankar, F.; Picchio, R. Soil recovery assessment after timber harvesting based on the Sustainable Forest Operation (SFO) perspective in Iranian temperate forests. Sustainability 2020, 12,2874 [CrossRef]

5. DeArmond, D.; Ferraz, J.; Higuchi, N. Natural Recovery of Skid Trails. A Review. Can. J. For. Res. 2021, 51, 948-961. [CrossRef]

6. Labelle, E.R.; Kammermeier, M. Above- and belowground growth response of Picea abies seedlings exposed to varying levels of soil relative bulk density. Eur. J. For. Res. 2019, 138, 705-722. [CrossRef]

7. Picchio, R.; Tavankar, F.; Nikooy, M.; Pignatti, G.; Venanzi, R.; Lo Monaco, A. Morphology, growth and architecture response of beech (Fagus orientalis Lipsky) and maple tree (Acer velutinum Boiss.) seedlings to soil compaction stress caused by mechanized logging operations. Forests 2019, 10, 771. [CrossRef]

8. Jourgholami, M.; Fathi, K.; Labelle, E.R. Effects of litter and straw mulch amendments on compacted soil properties and Caucasian alder (Alnus subcordata) growth. New For. 2020, 51, 349-365. [CrossRef]

9. Flores Fernández, J.L.; Hartmann, P.; Schäffer, J.; Pulhmann, H.; von Wilpert, K. Initial recovery of compacted soil-planting and technical treatments decrease $\mathrm{CO}_{2}$ concentrations in soil and promote root growth. Ann. For. Sci. 2017, 74, 73. [CrossRef]

10. Hansson, L.; Šimůnek, J.; Ring, E.; Bishop, K.; Gärdenäs, A.I. Soil compaction effects on root-zone hydrology and vegetation in boreal forest clearcuts. Soil Sci. Soc. Am. J. 2019, 83, S105-S115. [CrossRef]

11. Ugawa, S.; Inagaki, Y.; Karibu, F.; Tateno, R. Effects of soil compaction by a forestry machine and slash dispersal on soil N mineralization in Cryptomeria japonica plantations under high precipitation. New For. 2020, 51, 887-907. [CrossRef]

12. Jourgholami, M.; Feghhi, J.; Picchio, R.; Tavankar, F.; Venanzi, R. Efficiency of leaf litter mulch in the restoration of soil physiochemical properties and enzyme activities in temporary skid roads in mixed high forests. Catena 2021, $198,105012$. [CrossRef]

13. Smets, T.; Poesen, J.; Knapen, A. Spatial scale effects on the effectiveness of organic mulches in reducing soil erosion by water. Earth Sci. Rev. 2008, 89, 1-12. [CrossRef]

14. Kader, M.A.; Senge, M.; Mojid, M.A.; Ito, K. Recent advances in mulching materials and methods for modifying soil environment. Soil Tillage Res. 2017, 168, 155-166. [CrossRef]

15. Li, R.; Li, Q.; Pan, L. Review of organic mulching effects on soil and water loss. Arch. Agron. Soil Sci. 2021, 67, 136-151. [CrossRef]

16. Chalker-Scott, L. Impact of mulches on landscape plants and the environment-a review. J. Environ. Hortic. 2007, 25, 239-249. [CrossRef]

17. Jordán, A.; Zavala, L.M.; Muñoz-Rojas, M. Mulching, Effects on Soil Physical Properties. In Encyclopedia of Agrophysics; Gliński, J., Horabik, J., Lipiec, J., Eds.; Encyclopedia of Earth Sciences Series; Springer: Dordrecht, The Netherlands, 2011. [CrossRef]

18. Wagenbrenner, J.W.; MacDonald, L.H.; Rough, D. Effectiveness of three post-fire rehabilitation treatments in the Colorado Front Range. Hydrol. Process 2006, 20, 2989-3006. [CrossRef] 
19. Wagenbrenner, J.W.; MacDonald, L.H.; Coats, R.N.; Robichaud, P.R.; Brown, R.E. Effects of post-fire salvage logging and a skid trail treatment on ground cover, soils, and sediment production in the interior western United States. For. Ecol. Manag. 2015, 335, 176-193. [CrossRef]

20. Mulumba, L.N.; Lal, R. Mulching effects on selected soil physical properties. Soil Tillage Res. 2008, 98, 106-111. [CrossRef]

21. Robichaud, P.R.; Lewis, S.A.; Wagenbrenner, J.W.; Ashmun, L.E.; Robert, E.; Brown, R.E. Post-fire mulching for runoff and erosion mitigation, Part I: Effectiveness at reducing hillslope erosion rates. Catena 2013, 105, 75-92. [CrossRef]

22. Prats, S.A.; Martins, M.A.S.; Malvar, M.C.; Ben-Hur, M.; Keizer, J.J. Polyacrylamide application versus forest residue mulching for reducing post-fire runoff and soil erosion. Sci. Total Environ. 2014, 468-469, 464-474. [CrossRef]

23. Vega, J.A.; Fernández, C.; Fonturbel, T.; González-Prieto, S.; Jiménez, E. Testing the effects of straw mulching and herb seeding on soil erosion after fire in a gorse shrubland. Geoderma 2014, 223-225, 79-87. [CrossRef]

24. Fernández, C.; Vega, J.A. Are erosion barriers and straw mulching effective for controlling soil erosion after a high severity wildfire in NW Spain? Ecol. Eng. 2016, 87, 132-138. [CrossRef]

25. Jourgholami, M.; Etehadi Abari, M. Effectiveness of sawdust and straw mulching on postharvest runoff and soil erosion of a skid trail in a mixed forest. Ecol. Eng. 2017, 109, 1-9. [CrossRef]

26. Jourgholami, M.; Nasirian, A.; Labelle, E.R. Ecological restoration of compacted soil following the application of different leaf litter mulches on the skid trail over a five-year period. Sustainability 2018, 10, 2148. [CrossRef]

27. Jourgholami, M.; Ahmadi, M.; Tavankar, F.; Picchio, R. Effectiveness of three post-harvest rehabilitation treatments for runoff and sediment reduction on skid trails in the hyrcanian forests. Croat. J. For. Eng. 2020, 41, 309-324. [CrossRef]

28. Jourgholami, M.; Labelle, E.R. Effects of plot length and soil texture on runoff and sediment yield occurring on machine-trafficked soils in a mixed deciduous forest. Ann. For. Sci. 2020, 77, 19. [CrossRef]

29. Ring, E.; Andersson, M.; Hansson, L.; Jansson, G.; Högbom, L. Logging mats and logging residue as ground protection during forwarder traffic along till hillslopes. Croat. J. For. Eng. 2021. [CrossRef]

30. Kranz, C.N.; McLaughlin, R.A.; Johnson, A.; Miller, G.; Heitman, J.L. The effects of compost incorporation on soil physical properties in urban soils-A concise review. J. Environ. Manag. 2020, 261, 110209. [CrossRef]

31. Jordán, A.; Zavala, L.M.; Gil, J. Effects of mulching on soil physical properties and runoff under semi-arid conditions in southern Spain. Catena 2010, 81,77-85. [CrossRef]

32. Iqbal, R.; Raza, M.A.S.; Valipour, M.; Saleem, M.F.; Zaheer, M.S.; Ahmad, S.; Toleikiene, M.; Haider, I.; Aslam, M.U.; Nazar, M.A. Potential agricultural and environmental benefits of mulches-A review. Bull. Natl. Res. Cent. 2020, 44, 75. [CrossRef]

33. Hagen-Thorn, A.; Callesen, I.; Armolaitis, K.; Nihlgard, B. The impact of six European tree species on the chemistry of mineral topsoil in forest plantations on former agricultural land. For. Ecol. Manag. 2004, 195, 373-384. [CrossRef]

34. Langenbruch, C.; Helfrich, M.; Flessa, H. Effects of beech (Fagus sylvatica), ash (Fraxinus excelsior) and lime (Tilia spec.) on soil chemical properties in a mixed deciduous forest. Plant Soil 2012, 352, 389-403. [CrossRef]

35. Aponte, C.; García, L.V.; Marañón, T. Tree species effects on nutrient cycling and soil biota: A feedback mechanism favoring species coexistence. For. Ecol. Manag. 2013, 309, 36-46. [CrossRef]

36. Diao, M.; Yang, K.; Zhu, J.; Li, M.; Xu, S. Native broad-leaved tree species play key roles on maintaining soil chemical and microbial properties in a temperate secondary forest, Northeast China. For. Ecol. Manag. 2020, 462, 117971. [CrossRef]

37. Lucas-Borja, M.E.; de Santiago, J.H.; Yang, Y.; Shen, Y.; Candel-Pérez, D. Nutrient, metal contents and microbiological properties of litter and soil along a tree age gradient in Mediterranean forest ecosystems. Sci. Total Environ. 2019, 650, 749-758. [CrossRef]

38. Zhu, L.; Wang, X.; Chen, F.; Li, C.; Wu, L. Effects of the successive planting of Eucalyptus urophylla on soil bacterial and fungal community structure, diversity, microbial biomass, and enzyme activity. Land Degrad. Dev. 2019, 30, 636-646. [CrossRef]

39. Mayer, M.; Prescott, C.E.; Abaker, W.E.A.; Augusto, L.; Cécillon, L.; Ferreira, G.W.D.; James, J.; Jandl, R.; Katzensteiner, K.; Laclau, J.-P.; et al. Tamm review: Influence of forest management activities on soil organic carbon stocks: A knowledge synthesis. For. Ecol. Manag. 2020, 466, 118127. [CrossRef]

40. Sayer, E.J. Using experimental manipulation to assess the roles of leaf litter in the functioning of forest ecosystems. Biol. Rev. 2006, 81, 1-31. [CrossRef] [PubMed]

41. Prescott, C.E.; Vesterdal, L. Tree species effects on soils in temperate and boreal forests: Emerging themes and research needs. Forest Ecol. Manag. 2013, 309, 1-3. [CrossRef]

42. Mueller, K.E.; Hobbie, S.E.; Chorover, J.; Reich, P.B.; Eisenhauer, N.; Castellano, M.J.; Chadwick, O.A.; Dobies, T.; Hale, C.M.; Jagodziński, A.M.; et al. Effects of litter traits, soil biota, and soil chemistry on soil carbon stocks at a common garden with 14 tree species. Biogeochemistry 2015, 123, 313-327. [CrossRef]

43. Vauramo, S.; Setälä, H. Decomposition of labile and recalcitrant litter types under different plant communities in urban soils. Urban Ecosyst. 2011, 14, 59-70. [CrossRef]

44. Yang, K.; Zhu, J.J. Impact of tree litter decomposition on soil biochemical properties obtained from a temperate secondary forest in Northeast China. J. Soils Sediments 2015, 15, 13-23. [CrossRef]

45. Mohieddinne, H.; Brasseur, B.; Spicher, F.; Gallet-Moron, E.; Buridant, J.; Kobaissi, A.; Horen, H. Physical recovery of forest soil after compaction by heavy machines, revealed by penetration resistance over multiple decades. For. Ecol. Manag. 2019, 449, 117472. [CrossRef]

46. Zagyvai-Kiss, K.A.; Kalicz, P.; Szilágyi, J.; Gribovszki, Z. On the specific water holding capacity of litter for three forest ecosystems in the eastern foothills of the Alps. Agric. For. Meteorol. 2019, 278, 107656. [CrossRef] 
47. Gee, G.W.; Bauder, J.W. Particle-size analysis. In Methods of Soil Analysis, Part 1. Physical and Mineralogical Methods; Klute, A., Ed.; Soil Science Society of America: Madison, WI, USA, 1986; pp. 383-411.

48. Danielson, R.E.; Southerland, P.L. Methods of Soil Analysis. Part I. Physical and Mineralogical Methods, 2nd ed.; ASA, SSSA: Madison, WI, USA, 1986; pp. 443-460.

49. Kemper, W.D.; Rosenau, R.C. Aggregate stability and size distribution. In Methods of Soil Analysis. Physical and Mineralogical Properties. Part I, 2nd ed.; Klute, A., Ed.; Agronomy; ASA-SSSA: Madison, WI, USA, 1986; Volume 9, pp. 425-442.

50. Walkley, A.; Black, I.A. An examination of the Degtjareff method for determining soil organic matter and a proposed modification of chromic acid titration method. Soil Sci. 1934, 37, 29-38. [CrossRef]

51. Kooch, Y.; Zaccone, C.; Lamersdorf, N.P.; Tonon, G. Pit and mound influence on soil features in an Oriental Beech (Fagus Orientalis Lipsky) forest. Eur. J. For. Res. 2014, 133, 347-354. [CrossRef]

52. Salehi, A.; Ghorbanzadeh, N.; Kahneh, E. Earthworm biomass and abundance, soil chemical and physical properties under different poplar plantations in the north of Iran. J. For. Sci. 2013, 59, 223-229. [CrossRef]

53. Etehadi Abari, M.; Majnounian, B.; Malekian, A.; Jourgholami, M. Effects of forest harvesting on runoff and sediment characteristics in the Hyrcanian forests, northern Iran. Eur. J. For. Res. 2017, 136, 375-386. [CrossRef]

54. Schweier, J.; Blagojević, B.; Venanzi, R.; Latterini, F.; Picchio, R. Sustainability assessment of alternative strip clear cutting operations for wood chip production in renaturalization management of pine stands. Energies 2019, 12, 3306. [CrossRef]

55. Majnounian, B.; Jourgholami, M. Effect of rubber-tired cable skidder on soil compaction in Hyrcanian forest. Croat. J. For. Eng. 2013, 34, 123-135.

56. Jacobs, D.F.; Rose, R.; Haase, D.L.; Morgan, P.D. Influence of nursery soil amendments on water relations, root architectural development and field performance of Douglas-fir transplants. New For. 2003, 26, 263-277. [CrossRef]

57. Vincent, A.; Davies, S.J. Effects of nutrient addition, mulching and planting hole size on early performance of Dryobalanops aromatica and Shorea parvifolia planted in secondary forest in Sarawak, Malaysia. For. Ecol. Manag. 2003, 180, 261-271. [CrossRef]

58. Fang, S.; Xie, B.; Liu, D.; Liu, J. Effects of mulching materials on nitrogen mineralization, nitrogen availability and poplar growth on degraded agricultural soil. New For. 2011, 41, 147-162. [CrossRef]

59. Zhao, L.; Hou, R.; Fang, Q. Differences in interception storage capacities of undecomposed broad-leaf and needle-leaf litter under simulated rainfall conditions. For. Ecol. Manag. 2019, 446, 135-142. [CrossRef]

60. Xu, S.; Liu, L.L.; Sayer, E.J. Variability of above-ground litter inputs alters soil physicochemical and biological processes: A meta-analysis of litterfall manipulation experiments. Biogeosciences 2013, 10, 7423-7433. [CrossRef]

61. Ampoorter, E.; De Schrijver, A.; De Frenne, P.; Hermy, M.; Verheyen, K. Experimental assessment of ecological restoration options for compacted forest soils. Ecol. Eng. 2011, 37, 1734-1746. [CrossRef]

62. Cools, N.; Vesterdal, L.; De Vos, B.; Vanguelova, E.; Hansen, K. Tree species is the major factor explaining C:N ratios in European forest soils. For. Ecol. Manag. 2014, 311,3-16. [CrossRef]

63. Marty, C.; Houle, D.; Gagnon, C.; Courchesne, F. The relationships of soil total nitrogen concentrations, pools and C:N ratios with climate, vegetation types and nitrate deposition in temperate and boreal forests of eastern Canada. Catena 2017, 152, 163-172. [CrossRef]

64. Ren, X.; Jia, Z.; Chen, X.; Han, J.; Han, Q. Effect of ridge and furrow planting of rain- fall harvesting on soil available nutrient distribution and root growth of summer corn under simulated rainfall conditions. Trans. Chin. Soc. Agric. Eng. 2007, $23,94-99$.

65. Althoff, P.S.; Todd, T.C.; Thien, S.J.; Callaham, M.A., Jr. Response of soil microbial and invertebrate communities to tracked vehicle disturbance in tallgrass prairie. Appl. Soil Ecol. 2009, 43, 122-130. [CrossRef]

66. Kasirajan, S.; Ngouajio, M. Polyethylene and biodegradable mulches for agricultural applications: A review. Agron. Sustain. Dev. 2012, 32, 501-529. [CrossRef]

67. Goutal, N.; Renault, P.; Ranger, J. Forwarder traffic impacted over at least four years soil air composition of two forest soils in northeast France. Geoderma 2013, 193-194, 29-40. [CrossRef]

68. Cambi, M.; Grigolato, S.; Neri, F.; Picchio, R.; Marchi, E. Effects of forwarder operation on soil physical characteristics: A case study in the Italian alps. Croat. J. For. Eng. 2016, 37, 233-239. 